\title{
Palladium-catalyzed selective cycloaddition of diazo compounds to [60]fullerene
}

\author{
Airat R. Tuktarov, * Arslan R. Akhmetov, Vyacheslav V. Korolev, Artur A. Khuzin, Liliya \\ L. Khasanova, Natal'ya R. Popod'ko, and Leonard M. Khalilov \\ Institute of Petrochemistry and Catalysis, Russian Academy of Sciences, 141 Prospekt \\ Oktyabrya, Ufa 450075, Russia \\ E-mail: airat_1@mail.ru
}

\section{Dedicated to Professor Usein M. Dzhemilev on the occasion of his $65^{\text {th }}$ birthday}

\begin{abstract}
The effective catalytic method for cycloaddition of higher diazoalkanes and diazoacetates to [60]fullerene in the presence of the three-component catalytic system $\mathrm{Pd}(\mathrm{acac})_{2}-\mathrm{PPh}_{3}-\mathrm{Et}_{3} \mathrm{Al}$ has been developed. The yield and selective formation of the target homo- and methanofullerenes are dependent upon the structure of the original diazo compounds.
\end{abstract}

Keywords: [60]Fullerene, diazo compounds, cycloaddition, metal complex catalysts, homofullerene, methanofullerene

\section{Introduction}

Homofullerenes and methanofullerenes, synthesized via the 1,3-dipolar cycloaddition between diazo compounds and [60]fullerene or obtained by the Bingel-Hirsch reaction, appear to be one of the most perspective classes of fullerene derivatives as novel materials for various fields of science and technology as evidenced by the numerous reviews ${ }^{1,2}$ of both methods for a synthesis of these cycloadducts ${ }^{1}$ and their possible applications. ${ }^{2}$

The Bingel-Hirsch reaction for the synthesis of methanofullerenes is the most cited in the scientific literature. In our view, the reaction of fullerenes with diazo compounds due to its great synthetic potential is regarded as a very promising method to synthesize methanofullerenes and also allows, together with the [6,6]-closed adducts, obtaining the [5,6]-open isomeric ones.

Analysis of domestic and foreign literature has shown that cycloaddition between diazo compounds and [60]fullerene under thermal conditions appears to be nonselective. It is accompanied by the formation of a mixture of [6,6]-closed (methanofullerenes) and stereoisomeric [5,6]-open (homofullerenes) adducts. ${ }^{3}$ While exploiting $\mathrm{Rh}_{2}(\mathrm{OAc})_{4}$ as a promoter, 
this reaction selectively affords methanofullerenes. ${ }^{4}$ But the use of stoichiometric quantities of expensive Rh compounds is considered to be the substantial limitation of this method.

Taking the above into consideration, there is an important and urgent need to study and develop the catalytic cycloaddition methods for the effective synthesis of homo- and methanofullerenes, containing different functional groups, from diazo compounds and carbon clusters.

Over the past 5-10 years, we have been actively engaged in research of the cycloaddition reaction between diazo compounds and [60]fullerene under catalytic conditions and found that among the tested complexes and salts of $\mathrm{Cu}, \mathrm{Pd}$ and $\mathrm{Rh}$ a three-component catalytic system $\mathrm{Pd}(\mathrm{acac})_{2}-\mathrm{PPh}_{3}-\mathrm{Et}_{3} \mathrm{Al}$ has the greatest efficiency and selectivity in the reactions of $\mathrm{C}_{60}$ with the simplest diazoalkanes, ${ }^{5}$ diazoacetates, ${ }^{6,7}$ and diazoketones ${ }^{8}$ to promote the selective formation of the corresponding homo- or methanofullerenes.

Herein, we attempted to explore the application boundaries of the cycloaddition reaction of diazo compounds to $\mathrm{C}_{60}$ in the presence of $\mathrm{Pd}(\mathrm{acac})_{2}-\mathrm{PPh}_{3}-\mathrm{Et}_{3} \mathrm{Al}$ catalyst on the example of symmetric and asymmetric diazoalkanes and also higher diazoacetates of various structure.

\section{Results and Discussion}

Recently, we have implemented selective cycloaddition between [60]fullerene and diazoalkanes generated in situ through oxidation of hydrazones of acetaldehyde, benzaldehyde and acetone mediated by $\mathrm{Ag}_{2} \mathrm{O}$ or $\mathrm{MnO}_{2}$ in the presence of $20 \mathrm{~mol} \% \mathrm{Pd}(\mathrm{acac})_{2}-\mathrm{PPh}_{3}-\mathrm{Et}_{3} \mathrm{Al}$ (1:2:4) catalyst $\left(20^{\circ} \mathrm{C}, 30 \mathrm{~min}\right)$ leading to the exclusive formation of homofullerenes in $55-70 \%$ yields. ${ }^{5}$

In continuation of these studies and also to examine the effect of alkyl substituent size in the original diazoalkanes upon the selectivity of the reaction, we have carried out catalytic cycloaddition between $\mathrm{C}_{60}$ and diazoalkanes generated in situ by oxidation of hydrazones of butiric, valeric and caproic aldehydes. The above reaction was found to provide the formation of the corresponding homofullerenes 1-3 (Scheme 1), while the yield of target [5,6]-open adducts decreases slightly with increasing the alkyl chain length of diazoalkane.
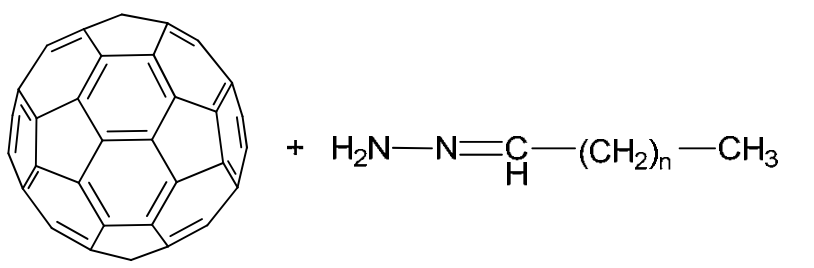

$\mathrm{MnO}_{2}, 20^{\circ} \mathrm{C}, 30 \mathrm{~min}$

$\mathrm{Pd}(\mathrm{acac})_{2}-2 \mathrm{PPh}_{3}-4 \mathrm{Et}_{3} \mathrm{Al}$

$$
\text { 1: } n=2(50 \%) ; \quad 2: n=3(47 \%) ; \quad 3: n=4(40 \%)
$$

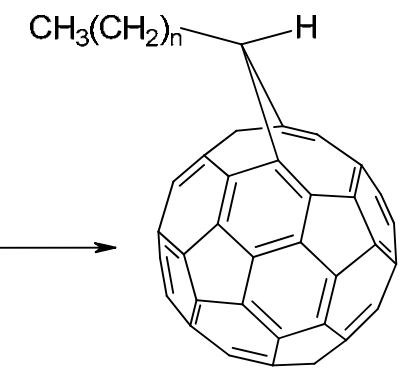

1-3

Scheme 1. Catalytic cycloaddition of mono substituted diazomethanes to fullerene[60]. 
The chemical structure of $\mathbf{1}-\mathbf{3}$ was proven by means of one-dimentional $\left({ }^{1} \mathrm{H},{ }^{13} \mathrm{C}\right)$ and twodimentional (HSQC, HMBC, HH COSY) NMR spectroscopy as well as IR, UV spectroscopy and MALDI TOF/TOF mass spectrometry.

Thus, the formation of homofullerene 1 containing the hydrogen atom at the bridging $\mathrm{C}$ atom above the plane of a six-membered ring of $\mathrm{C}_{60}$ has been proven on the basis of the characteristic triplet signal of the methine hydrogen atom at $\delta(\mathrm{H}) 2.78 \mathrm{ppm}(\mathrm{J}=7.6 \mathrm{~Hz})$.

The ${ }^{1} \mathrm{H}$ NMR spectrum of $\mathbf{1}$ (Figure 1) is also characterized by a set of signals: triplet $[\delta(\mathrm{H})$ $1.26 \mathrm{ppm}(J=7.6 \mathrm{~Hz})]$, quartet $[\delta(\mathrm{H}) 3.49 \mathrm{ppm}(J=7.6 \mathrm{~Hz}))$ and sextet $[\delta(\mathrm{H})=1.95 \mathrm{ppm}(J=$ $7.6 \mathrm{~Hz}$ )], belonging to the hydrogen atoms of the propyl group at the bridging carbon atom.

In the ${ }^{13} \mathrm{C}$ NMR spectrum the bridging $\mathrm{C}$ atom resonates at $\delta(\mathrm{C}) 49.06 \mathrm{ppm}$, while the $s p^{2}$ hybridized C atoms of the fullerene skeleton are manifested in the field of 134-148 ppm. Similarly, we proved the structure of compounds $\mathbf{2}$ and $\mathbf{3}$.

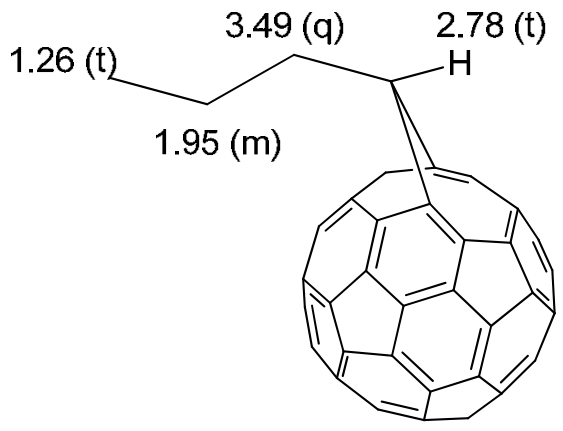

Figure 1. ${ }^{1} \mathrm{H}$ NMR data for compound 1.

In contrast to mono-substituted diazoalkanes, the reaction of [60]fullerene with diazoalkanes, in situ generated from hydrazones of methyl ethyl ketones or methyl hexyl ketones, under optimized conditions $\left(20 \mathrm{~mol} \% \mathrm{Pd}(\mathrm{acac})_{2}-2 \mathrm{PPh}_{3}-4 \mathrm{Et}_{3} \mathrm{Al}, 20{ }^{\circ} \mathrm{C}, 30 \mathrm{~min}\right)$ gave rise to a mixture of stereoisomeric homofullerenes $\mathbf{4 a}, \mathbf{b}$ and $\mathbf{5 a}, \mathbf{b}$ (Scheme 2).

Apparently, the decrease in the selectivity of the reaction is conditioned by the presence of the second alkyl substituent at the bridging $\mathrm{C}$ atom of the cycloadduct raising the probability of the stereoisomeric $[5,6]$-open adduct formation.

It was noted that if negligible difference between substituents in the initial hydrazones, for example, hydrazone of methyl ethyl ketone, the ratio of stereoisomeric homofullerenes tends to unity.

The increase in alkyl chain length of the substituent leads to the predominant formation of the energetically more stable homofullerene with the more bulky substitutent located above the plane of the five-membered ring of the $\mathrm{C}_{60}$ molecule (Scheme 2). 


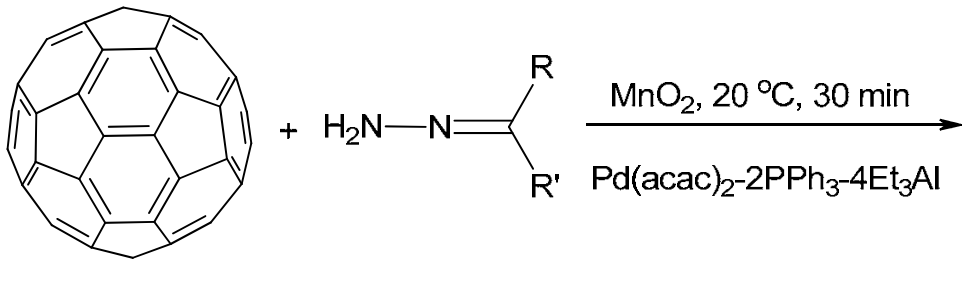

$$
\text { a: } R=M e, R^{\prime}=\operatorname{Et}(45 \%) ; \quad \text { b: } R=M e, R^{\prime}=\operatorname{Hex}(40 \%)
$$

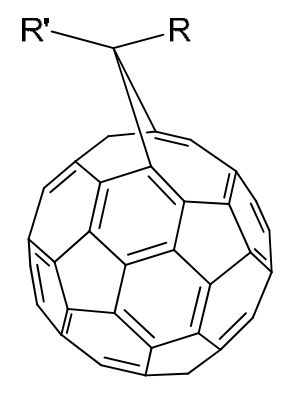

$4 \mathbf{a , b}$

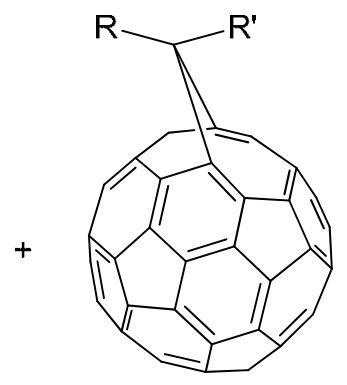

5 a,b

Scheme 2. Interaction of fullerene[60] with asymmetrical diazoalkanes in the presence of Pdcomplex.

The mixtures of products $\mathbf{4 , 5 a , b}$ and fullerene were isolated by preparative HPLC. 1D $\left({ }^{1} \mathrm{H}\right.$ and ${ }^{13} \mathrm{C}$ NMR, DEPT, $135^{\circ} \mathrm{C}$ ) and $2 \mathrm{D}$ (HHCOSY, HSQC, HMBC) experiments demonstrated that compounds $\mathbf{4 , 5 a , b}$ consisted of a mixture stereoisomers of 5,6-open fullerene monoadducts. We failed to separate adducts $\mathbf{4}$ and $\mathbf{5}$ since their physicochemical constants and polarity at chromatography were too close.

The ratio of stereoisomeric homofullerenes $\mathbf{4 a}$ and $\mathbf{5 a}$ as well as $\mathbf{4 b}$ and $\mathbf{5 b}$ was 3:2 and 3:1, respectively, and was estimated on the basis of integral curves of the characteristic singlet signals of the methyl group at the bridging $\mathrm{C}$ atom the ${ }^{1} \mathrm{H}$ NMR spectrum of corresponding mixtures.

The location of the methyl group at the bridging $\mathrm{C}$ atom above the plane of the fivemembered or six-membered ring of the fullerene molecule in compounds $\mathbf{4 a , b}$ and $\mathbf{5 a , b}$ was defined by comparison between the characteristic singlet signals of the methyl hydrogen atoms in the ${ }^{1} \mathrm{H}$ NMR spectrum and the known analogues. ${ }^{3 a}$

Thus, the characteristic singlet signal of the methyl hydrogen atoms at the bridging $\mathrm{C}$ atom in the ${ }^{1} \mathrm{H}$ NMR spectrum of homofullerene $4 \mathrm{a}$ resonates at the higher field $[\delta(\mathrm{H}) 1.16 \mathrm{ppm}]$ than that of the stereoisomer $5 \mathbf{a}[\delta(\mathrm{H}) 3.12 \mathrm{ppm}]$ (Figure 2). In turn, the methylene $[\delta(\mathrm{H}) 3.72 \mathrm{ppm}(J$ $=7.2 \mathrm{~Hz})]$ and methyl $[\delta(\mathrm{H}) 1.54 \mathrm{ppm}(\mathrm{J}=7.2 \mathrm{~Hz})]$ hydrogen atoms of the ethyl substituent in $[5,6]$-open adduct $4 \mathbf{a}$ manifest themselves at the lower field as compared with the similar signals at $\delta(\mathrm{H}) 1.50 \mathrm{ppm}(J=7.2 \mathrm{~Hz})$ and $\delta(\mathrm{H}) 1.00 \mathrm{ppm}(J=7.2 \mathrm{~Hz})$ for compound $\mathbf{5 a}$. 


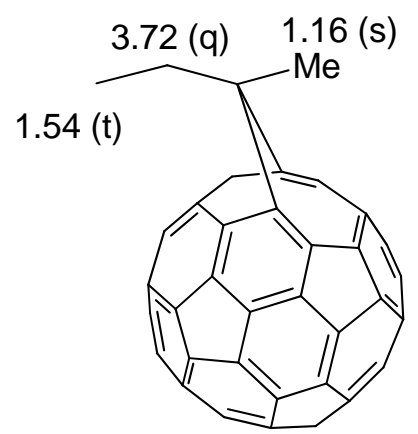

$4 a$

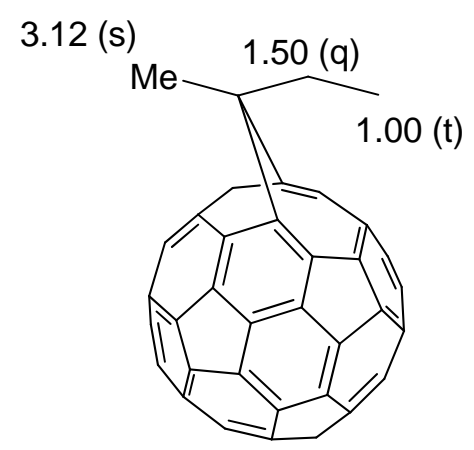

$5 a$

Figure 2. ${ }^{1} \mathrm{H}$ NMR data for compounds $\mathbf{4 a}$ and $\mathbf{5 a}$.

In order to study the possibility of the selective synthesis of homofullerenes containing heteroatoms, we have carried out cycloaddition between $\mathrm{C}_{60}$ and sulfur-containing asymmetric diazoalkanes generated by oxidation hydrazones of ketosulfides. Thus, the interaction between [60]fullerene and diazoalkanes, generated in situ by oxidation of hydrazones of 3(pentylthiomethyl)- and 3-(cyclohexylthiomethyl)-2-butanones with $\mathrm{MnO}_{2}$, in the presence of 20 $\mathrm{mol} \%$ three-component $\mathrm{Pd}(\mathrm{acac})_{2}-2 \mathrm{PPh}_{3}-4 \mathrm{Et}_{3} \mathrm{Al}$ catalyst was found to afford predominantly the corresponding homofullenes 6 and 7 in 50\% yield (Scheme 3).

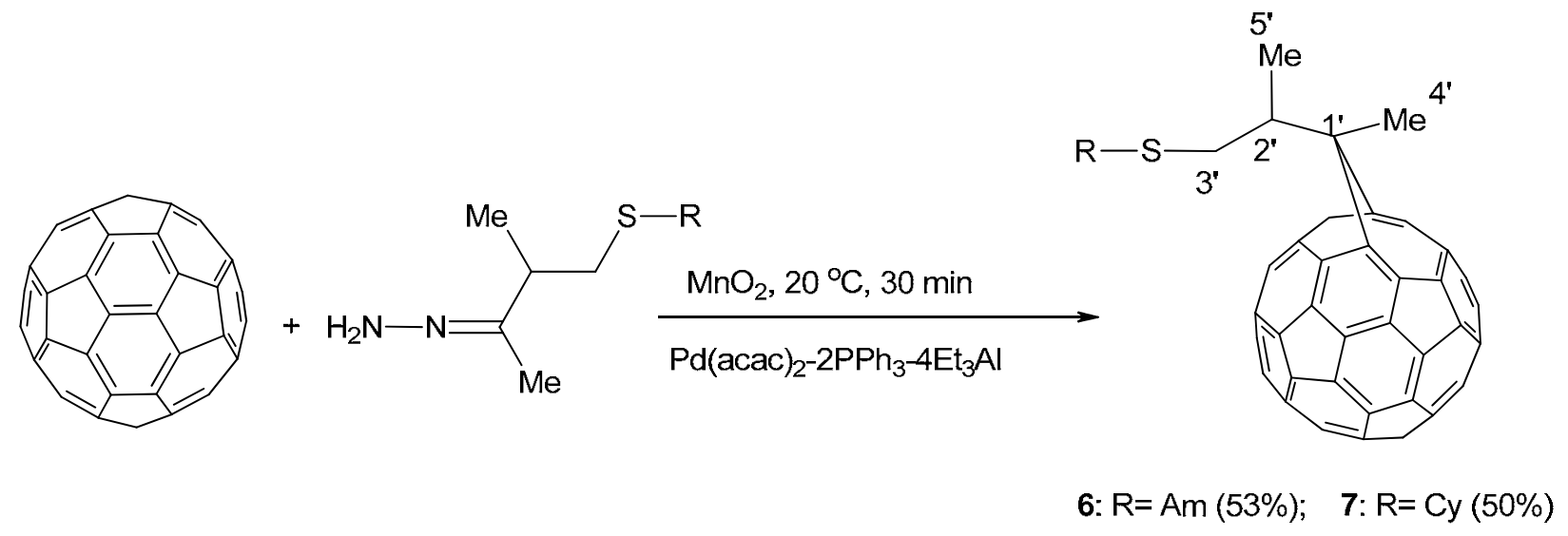

Scheme 3. Catalytic synthesis of sulfur-containing homofullerenes.

Their structure has been confirmed by means of negative ion MALDI TOF/TOF MS, oneand two-dimensional $\left({ }^{1} \mathrm{H},{ }^{13} \mathrm{C}\right.$, COSY, HSQC and HMBC) NMR experiments and also by analysis of UV and IR spectra.

Thus, the molecular peak $\mathrm{m} / \mathrm{z} 892.984$ corresponding to empiric formula $\mathrm{C}_{70} \mathrm{H}_{20} \mathrm{~S}$ was observed in the mass spectrum of compound $\mathbf{6}$ recorded in the negative-ion mode in the absence of a matrix (unionized molecules of original homofullerene as matrix). 
The ${ }^{1} \mathrm{H}$ NMR spectrum of 6 (Figure 3) reveals ABX spin system of the methine hydrogen atom with a chemical shift $\delta\left(\mathrm{HC}^{2}\right) 5.21 \mathrm{ppm}$ and two diastereotopic hydrogen atoms of methylene groups $\left[\delta\left(\mathrm{H}^{\mathrm{a}} \mathrm{C}^{3}\right) 2.78\right.$ and $\left.\delta\left(\mathrm{H}^{\mathrm{b}} \mathrm{C}^{3^{\prime}}\right) 3.16 \mathrm{ppm}\right]$ coupled to each other through the combination of geminal spin-spin $\left[{ }^{2} \mathrm{JH}^{\mathrm{a}} \mathrm{H}^{\mathrm{b}}=12.8 \mathrm{~Hz}\right]$ and vicinal $\left[{ }^{3} \mathrm{~J}^{\mathrm{a}} \mathrm{H}_{2}=9.2\right.$ and ${ }^{3} \mathrm{JH}^{\mathrm{b}} \mathrm{H}_{2}=$ $4.8 \mathrm{~Hz}]$ interactions.

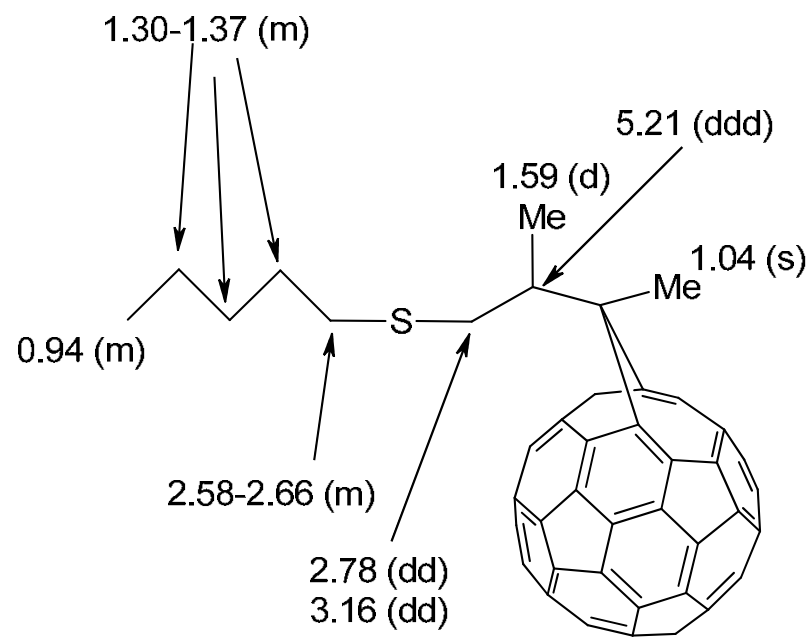

6

Figure 3. ${ }^{1} \mathrm{H}$ NMR data for compound 6 .

The thiopentyl fragment is described by five carbon signals correlated with five groups of signals of hydrogen atoms in HSQC experiment. The methyl group at $\delta\left(\mathrm{H}_{3} \mathrm{C}^{5}\right) 1.59 \mathrm{ppm}\left[\delta\left(\mathrm{C}^{5}\right)\right.$ $29.64 \mathrm{ppm}]$, directly linked with the chiral center $\mathrm{C}^{2}$, can be observed as the doublet signal in ${ }^{1} \mathrm{H}$ NMR spectrum $\left({ }^{3} J=6.8 \mathrm{~Hz}\right)$, while the methyl group at $\delta\left(\mathrm{H}_{3} \mathrm{C}^{4}\right) 1.04 \mathrm{ppm}\left(\delta\left(\mathrm{C}^{4}\right) 13.96 \mathrm{ppm}\right)$ is represented by a singlet signal in the high field.

The high-field shielding of the methyl group at $\mathrm{C}^{4}$ in both ${ }^{1} \mathrm{H}$ and ${ }^{13} \mathrm{C}$ spectra evidenced of its location above the plane of the fullerene six-membered ring unlike the low-field shift of the methine proton $\left[\delta\left(\mathrm{HC}^{2}\right) 5.21 \mathrm{ppm}\right]$ above the plane of the fullerene five-membered ring in $[5,6]-$ open adduct 6 .

Increasing a number of signals of the fullerene carbon atoms up to 40 due to anisotropic influence on the chiral centre at $\mathrm{C}^{2}$ atom leads to the diastereotopic splitting of signals of the carbon atoms in the $\alpha, \beta$ and $\gamma$ environments towards the bridging $C^{1}$ atom.

The presence of the minor signals in the ${ }^{1} \mathrm{H}$ and ${ }^{13} \mathrm{C}$ NMR spectra (1:10 ratio) indicate the presence of stereoisomer of homofullerene 6 with the methyl group at the bridging $\mathrm{C}$ atom located above the plane of the five-membered ring of fullerene $\mathrm{C}_{60}$ molecule. But the low content of this isomer in the reaction mixture has not allowed characterizing it reliably.

Our subsequent efforts have been focused on the possibilities to synthesize carboxy derivatives of methanofullerenes bearing various substituents in the ester group. 
At the same time, we were intended to study the influence of the original diazoacetate nature upon the yield of the target cycloadducts. We believed that positive results obtained, in the future, will allow synthesizing functionally substituted methanofullerenes containing complex moieties of the steroid series being identical in all respects (composition, configuration, conformation) with the natural compound.

Taking into account the resulting data, ${ }^{6}$ we have implemented cycloaddition between diazoacetic esters and [60]fullerene in the presence of the catalytic system $\mathrm{Pd}(\mathrm{acac})_{2}-\mathrm{PPh}_{3}-\mathrm{Et}_{3} \mathrm{Al}$ (1:4:4 ratio) to selectively produce the appropriate $[6,6]$-close adducts.

Realization of the planned study on cycloaddition between $\mathrm{C}_{60}$ and diazoacetic esters bearing iso-propyl, cyclohexyl and tert-butyl substituents in the ester group under previously optimized conditions in the cycloaddition reaction for diazoacetates $\left(80{ }^{\circ} \mathrm{C}, 1 \mathrm{~h}, 20 \mathrm{~mol} \% \mathrm{Pd}(\mathrm{acac})_{2}-4 \mathrm{PPh}_{3}\right.$ $4 \mathrm{Et}_{3} \mathrm{Al}$ ) allowed to synthesize the appropriate methanofullerenes 8-10 in the yields of 70, 60 and $46 \%$ respectively (Scheme 4 ).

As noted, the use of diazoacetates bearing sterically hindered substituents in the ester group leads to some decrease in the yield of final products.

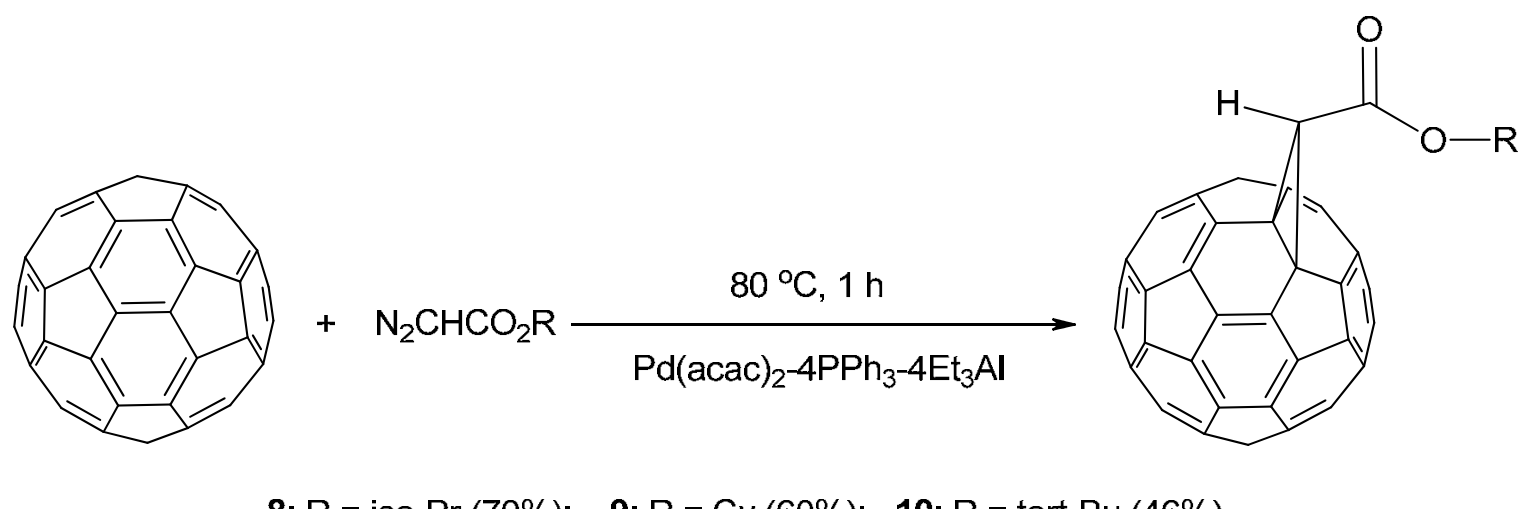

Scheme 4. Cycloaddition of diazo acetates to fullerene[60] in the presence of $\mathrm{Pd}(\mathrm{acac})_{2^{-}}-\mathrm{PPh}_{3^{-}}$ $4 \mathrm{Et}_{3} \mathrm{Al}$.

Very promising results on the synthesis of functionally substituted methanofullerenes, containing various sterically hindered substituents in the ester group, encouraged us to apply this reaction to the synthesis of methanofullerenes, which bear the carboxyl groups and complex natural moieties as well.

For the study we selected diazoacetate derived from glycine and cholesterol under previously developed conditions, ${ }^{6}$ and introduced it in the reaction with $\mathrm{C}_{60}$. As a result, methanofullerene 11 has been first obtained in 50\% yield in one preparative stage (Scheme 5).

As shown, the presence of steroid substituent in the ester group of the original diazo compound under catalytic conditions does not substantially reduce the yield of the target adduct. 


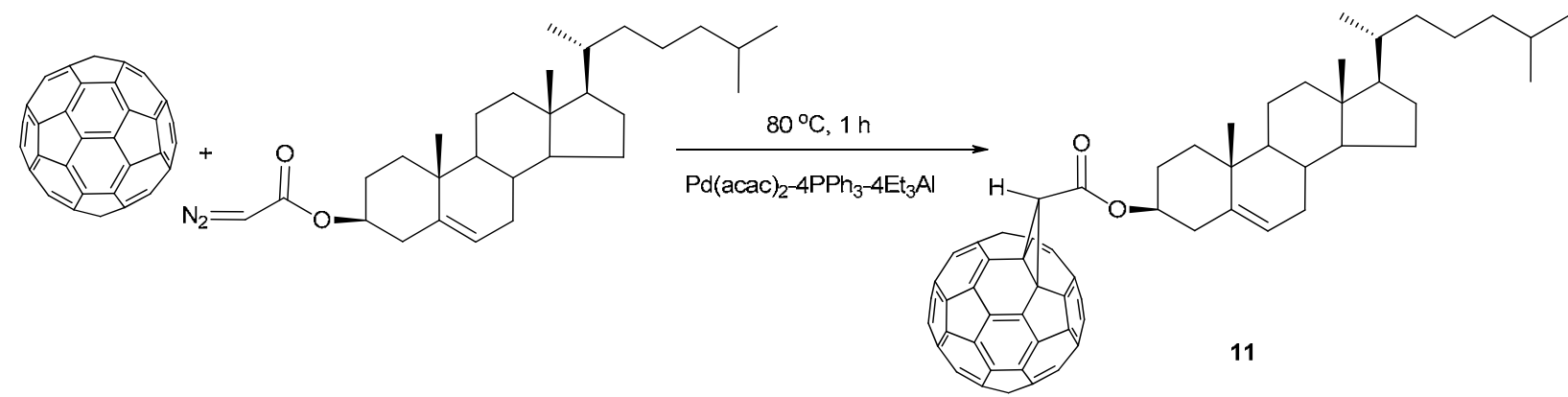

Scheme 5. Synthesis of functionally substituted methanofullerenes, containing sterically hindered substituent in the ester group.

The signals of $s p^{3}$-hybridized $\mathrm{C}$ atoms of the fullerene skeleton at $\delta_{\mathrm{C}} 70.87 \mathrm{ppm}$ and the methine $\mathrm{C}$ atom at $\delta(\mathrm{C}) 39.83 \mathrm{ppm}\left[\delta(\mathrm{H}) 4.74 \mathrm{ppm}\left({ }^{1} \mathrm{H}\right.\right.$ NMR)] in the ${ }^{13} \mathrm{C}$ NMR spectrum of 11 unambiguously evidenced for the formation of the cyclopropane fragment linked to the cholesterol residue via the carboxyl group [ $\delta$ (C) $164.79 \mathrm{ppm}]$.

The cholesterol fragment of the molecule in the ${ }^{13} \mathrm{C}$ NMR spectrum is represented by 24 signals resonated at the high field, which are characteristic of $s p^{3}$-hybridized $\mathrm{C}$ atoms of cholesterol [ $\delta(\mathrm{C}) 12-57 \mathrm{ppm}$ ], a carbinol signal at $\delta(\mathrm{C}) 76.40 \mathrm{ppm}$ and two signals of the double bond at $\delta$ (C) 123.66 and $139.09 \mathrm{ppm}$. The spectrum of $\mathbf{1 1}$ also shows 17 signals attributable to the fullerene skeleton in the field of $s p^{2}$-hybridized $\mathrm{C}$ atoms indicating the presence of two planes of symmetry in the molecule.

Currently, we are actively pursuing the synthesis of carboxy derivatives of methanofullerenes bearing in the ester group pharmavaluable preparations based on natural and synthetic diazo derivatives of terpenes, steroids, alkaloids and carbohydrates.

\section{Conclusions}

Thus, we have shown that the previously suggested three-component catalytic system $\operatorname{Pd}(\operatorname{acac})_{2}-$ $\mathrm{PPh}_{3}-\mathrm{Et}_{3} \mathrm{Al}$ can be successfully applied to the reaction of [60]fullerene with the simplest diazo compounds to synthesize higher homo- and methanofullerenes bearing substituents of various structure.

The interaction between $\mathrm{C}_{60}$ and diazoalkanes, generated in situ by oxidation of hydrazones derived from aldehydes, was stated to afford under catalytic conditions individual homofullerenes with the location of hydrogen atom at the bridging $\mathrm{C}$ atom above the plane of the fullerene six-membered ring. Replacing of mono-diazomethane in this reaction by disubstituted one resulted in the decrease in selectivity and is accompanied by the formation of a mixture of stereoisomeric [5,6]-open adducts. 
For the first time, carboxy derivatives of methanofullerenes have been synthesized in one preparative stage based upon diazoacetates containing in the ester group the steroid molecule such as cholesterol.

\section{Experimental Section}

General. Commercially available [60]fullerene (99.5\% pure, G. A. Razuvaev Institute of Organometallic Chemistry, Russian Academy of Sciences, Nizhniy Novgorod) was used. The reaction products were analyzied on a HPLC chromatograph Altex (model 330) (USA) equipped with the UV detector at $340 \mathrm{~nm}$. The mixtures were separated on a metal half-preparative column Cosmosil Buckyprep Waters $(250 \times 10 \mathrm{~mm})$ at $\sim 20^{\circ} \mathrm{C}$. Toluene was used as eluent, the flow rate was $2.0 \mathrm{~mL} \cdot \mathrm{min}^{-1}$. The IR spectra were registered on a VERTEX 70V (Bruker) spectrophotometer in $\mathrm{KBr}$ pellets. The UV spectra were recorded on a LAMBDA 750 (Perkin Elmer) in $\mathrm{CHCl}_{3}$. The ${ }^{1} \mathrm{H}$ and ${ }^{13} \mathrm{C}$ NMR spectra were run on a Bruker Avance-400 spectrometer at 400.13 and $100.62 \mathrm{MHz}$, respectively. The mixture of $\mathrm{CDCl}_{3}$ and $\mathrm{CS}_{2}$ (1:5) was used as a solvent. The negative ion mass spectra were obtained on a MALDI TOF/TOF Autoflex-III Bruker without a matrix operating in a linear mode. For the application on a metal target, the toluene solutions of the samples were used.

\section{Catalytic cycloaddition of diazoalkanes to [60]fullerene. General procedure}

A solutions of $\mathrm{Pd}(\mathrm{acac})_{2}(0.00278 \mathrm{mmol})$ in $O$-dichlorobenzene $(0.4 \mathrm{~mL})$ and $\mathrm{PPh}_{3}(0.00556$ $\mathrm{mmol})$ in $\mathrm{o}$-dichlorobenzene $(0.4 \mathrm{~mL})$ were mixted in the glas flask, then a solution of $\mathrm{Et}_{3} \mathrm{Al}$ $(0.01112 \mathrm{mmol})$ in toluene $(0.1 \mathrm{~mL})$ was added with stirring under stream of nitrogen at $-5{ }^{\circ} \mathrm{C}$. The color of the solution changed from light yellow to light brown. A solution of [60]fullerene $(0.0139 \mathrm{mmol})$ in $o$-dichlorobenzene $(0.1 \mathrm{~mL})$ was added to the resulting catalyst at room temperature, the color of the solution turned dark green. A solution of the corresponding hydrazone $(0.0695 \mathrm{mmol})$ in toluene $(0.5 \mathrm{~mL})$ and $\mathrm{MnO}_{2}(1 \mathrm{mmol})$ was added. The reaction mixture was stirred for $1-1.5 \mathrm{~h}$ at the ambient temperature, then treated with aqueous $\mathrm{HCl}$, extracted with toluene $(7 \mathrm{~mL})$. The organic layer was passed through short column filled with silica gel. The products 1-7 and [60]fullerene were separated by half-preparative HPLC, using toluene as eluent.

1a-Propyl-1aH-1(9)a-homo $\left(\mathbf{C}_{60}-I_{h}\right)\left[\mathbf{5 , 6 ] f u l l e r e n e ~ ( 1 ) . ~ I R ~ ( K B r ) ~} \vee 526,1145,1213,1438 \mathrm{sm}^{-1}\right.$; $\mathrm{UV}\left(\mathrm{CHCl}_{3}\right) \lambda_{\max } 262,333 \mathrm{~nm} ;{ }^{1} \mathrm{H}$ NMR $(400 \mathrm{MHz}) \delta 1.26\left(\mathrm{t},{ }^{3} \mathrm{~J}=7.6 \mathrm{~Hz}, 3 \mathrm{H}, \mathrm{CH}_{3}\right), 1.95(\mathrm{~m}$, 2H), $2.78\left(\mathrm{t},{ }^{3} \mathrm{~J}=7.6 \mathrm{~Hz}, \mathrm{H}, \mathrm{CH}\right), 3.49\left(\mathrm{q},{ }^{3} \mathrm{~J}=7.6 \mathrm{~Hz}, 2 \mathrm{H}, \mathrm{CH}_{2}\right) ;{ }^{13} \mathrm{C} \mathrm{NMR}(100 \mathrm{MHz}) \delta 14.68$, 22.37, 36.02, 49.06, 134.03, 134.62, 136.71, 138.17, 138.61, 138.89, 140.08, 140.28, 141.63, $142.04,142.18,142.60,142.74,142.92,143.20,143.40,143.56,143.71,143.97,144.36,144.92$, 145.00, 147.98; MS (MALDI-TOF/TOF) $\mathrm{m} / \mathrm{z}[\mathrm{M}]^{+}$found 776.780 , calculated $776.748, \mathrm{C}_{64} \mathrm{H}_{8}$.

1a-Butyl-1aH-1(9)a-homo $\left(\mathbf{C}_{60}-\boldsymbol{I}_{\boldsymbol{h}}\right)\left[\mathbf{5 , 6}\right.$ ]fullerene (2). IR (KBr) $\vee 526,1155,1213,1438 \mathrm{sm}^{-1}$; $\mathrm{UV}\left(\mathrm{CHCl}_{3}\right) \lambda_{\max } 262,331 \mathrm{~nm} ;{ }^{1} \mathrm{H} \mathrm{NMR}(400 \mathrm{MHz}) \delta 1.12\left(\mathrm{t},{ }^{3} \mathrm{~J}=7.6 \mathrm{~Hz}, 3 \mathrm{H}, \mathrm{CH}_{3}\right), 1.66(\mathrm{~m}$, 
2H), $1.89(\mathrm{~m}, 2 \mathrm{H}), 2.75\left(\mathrm{t},{ }^{3} \mathrm{~J}=7.6 \mathrm{~Hz}, \mathrm{H}, \mathrm{CH}\right), 3.50\left(\mathrm{q},{ }^{3} \mathrm{~J}=7.6 \mathrm{~Hz}, 2 \mathrm{H}, \mathrm{CH}_{2}\right) ;{ }^{13} \mathrm{C}$ NMR $(100$ $\mathrm{MHz}) \delta 14.60,23.41,31.17,33.76,49.27,134.02,134.60,138.14,138.60,138.89,140.06$, $140.34,141.62,141.99,142.04,142.17,142.25,142.60,142.73,142.91,143.11,143.17,143.20$, $143.47,143.55,143.69,143.71,143.75,143.96,144.36,144.91,144.99,145.51,147.97$; MS (MALDI-TOF/TOF) $\mathrm{m} / \mathrm{z}[\mathrm{M}]^{+}$found 790.808, calculated 790.775, $\mathrm{C}_{65} \mathrm{H}_{10}$.

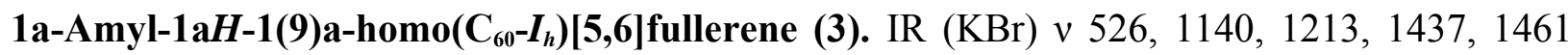
$\mathrm{sm}^{-1}$; UV $\left(\mathrm{CHCl}_{3}\right) \lambda_{\max } 262,333 \mathrm{~nm} ;{ }^{1} \mathrm{H} \mathrm{NMR}(400 \mathrm{MHz}) \delta 1.04\left(\mathrm{t},{ }^{3} \mathrm{~J}=7.6 \mathrm{~Hz}, 3 \mathrm{H}, \mathrm{CH}_{3}\right), 1.51$ (m, 2H), $1.63(\mathrm{~m}, 2 \mathrm{H}), 1.91(\mathrm{~m}, 2 \mathrm{H}), 2.75\left(\mathrm{t},{ }^{3} \mathrm{~J}=7.6 \mathrm{~Hz}, \mathrm{H}, \mathrm{CH}\right), 3.50\left(\mathrm{q},{ }^{3} J=7.6 \mathrm{~Hz}, 2 \mathrm{H}, \mathrm{CH}_{2}\right)$; ${ }^{13} \mathrm{C}$ NMR $(100 \mathrm{MHz}) \delta 14.56,23.28,28.74,32.31,34.01,49.30,134.02,134.60,138.14,138.60$, $138.89,140.06,140.35,141.62,142.04,142.18,142.26,142.60,142.74,142.92,143.11,143.18$, 143.20, 143.47, 143.56, 143.62, 143.69, 143.72, 143.75, 143.96, 144.36, 144.91, 145.00, 147.98; MS (MALDI-TOF/TOF) $\mathrm{m} / \mathrm{z}[\mathrm{M}]^{+}$found 804.849, calculated 804.802, $\mathrm{C}_{66} \mathrm{H}_{12}$.

Mixture of stereoisomeric 1a-methyl-1a-ethyl-1(9)a-homo $\left(\mathbf{C}_{60}-I_{h}\right)[5,6]$ fullerenes (4a and 5a). IR (KBr) $\vee 528,1131,1178,1207,1434,1462 \mathrm{sm}^{-1}$; UV $\left(\mathrm{CHCl}_{3}\right) \lambda_{\max } 262,333 \mathrm{~nm}$; MS (MALDI-TOF/TOF) $\mathrm{m} / \mathrm{z}[\mathrm{M}]^{+}$found 776.748, calculated 776.746, $\mathrm{C}_{64} \mathrm{H}_{8}$.

4a. ${ }^{1} \mathrm{H}$ NMR (400 MHz) $\delta 1.16\left(\mathrm{~s}, 3 \mathrm{H}, \mathrm{CH}_{3}\right), 1.54\left(\mathrm{t},{ }^{3} \mathrm{~J}=7.2 \mathrm{~Hz}, 3 \mathrm{H}, \mathrm{CH}_{3}\right), 3.72\left(\mathrm{q},{ }^{3} \mathrm{~J}=7.2 \mathrm{~Hz}\right.$, $\left.2 \mathrm{H}, \mathrm{CH}_{2},\right) ;{ }^{13} \mathrm{C}$ NMR $(100 \mathrm{MHz}) \delta 10.21,19.15,35.45,49.49,135.09,136.70,137.85,138.78$, $139.72,140.22$, 141.06, 141.50, 141.96, 142.00, 142.21, 142.33, 142.65, 142.78, 142.97, 143.04, $143.15,143.24,143.56,143.69,143.82,143.95,144.11,144.84,145.20,147.54$.

5a. ${ }^{1} \mathrm{H}$ NMR (400 MHz) $\delta 1.00\left(\mathrm{t},{ }^{3} \mathrm{~J}=7.2 \mathrm{~Hz}, 3 \mathrm{H}, \mathrm{CH}_{3}\right), 1.50\left(\mathrm{q},{ }^{3} \mathrm{~J}=7.2 \mathrm{~Hz}, 2 \mathrm{H}, \mathrm{CH}_{2}\right), 3.12(\mathrm{~s}$, $\left.3 \mathrm{H}, \mathrm{CH}_{3}\right) ;{ }^{13} \mathrm{C}$ NMR $(100 \mathrm{MHz}) \delta 8.81,26.84,27.42,48.93,134.98,135.95,137.16,137.83$, $138.78,139.63,141.44,141.91,142.02,142.18,142.21,142.59,142.85,143.15,143.69,143.75$, $144.48,145.22$.

Mixture of stereoisomeric 1a-methyl-1a-hexyl-1(9)a-homo $\left(\mathbf{C}_{60}-I_{\mathbf{h}}\right)[\mathbf{5 , 6}$ fullerenes (4b and 5b). IR (KBr) v 526, 1027, 1102, 1186, 1261, 1428, $1461 \mathrm{sm}^{-1}$; UV $\left(\mathrm{CHCl}_{3}\right) \lambda_{\max } 260,326 \mathrm{~nm}$; MS (MALDI-TOF/TOF) $\mathrm{m} / \mathrm{z}[\mathrm{M}]^{+}$found 832.914, calculated 832.855, $\mathrm{C}_{68} \mathrm{H}_{16}$.

4b. ${ }^{1} \mathrm{H}$ NMR (400 MHz) $\delta 0.99\left(\mathrm{t},{ }^{3} \mathrm{~J}=7.2 \mathrm{~Hz}, 3 \mathrm{H}, \mathrm{CH}_{3}\right), 1.17\left(\mathrm{~s}, 3 \mathrm{H}, \mathrm{CH}_{3}\right), 1.43-1.53(\mathrm{~m}, 4 \mathrm{H}$, $\left.2 \mathrm{CH}_{2}\right), 1.65\left(\mathrm{~m}, 2 \mathrm{H}, \mathrm{CH}_{2}\right), 1.95\left(\mathrm{~m}, 2 \mathrm{H}, \mathrm{CH}_{2}\right), 3.66\left(\mathrm{t},{ }^{3} \mathrm{~J}=7.2 \mathrm{~Hz}, 2 \mathrm{H}, \mathrm{CH}_{2}\right) ;{ }^{13} \mathrm{C} \mathrm{NMR}(100$ $\mathrm{MHz}) \delta 14.46,19.82,23.13,25.93,30.43,32.22,42.72,48.99,135.11,137.85,138.79,139.73$, $140.23,141.03,141.51,141.99,142.21,142.30,142.84,142.92,143.15,143.26,143.84,143.96$, 144.12, 144.86, 145.22, 147.56.

5b. ${ }^{1} \mathrm{H}$ NMR $(400 \mathrm{MHz}) \delta 0.94\left(\mathrm{t},{ }^{3} J=7.6 \mathrm{~Hz}, 3 \mathrm{H}, \mathrm{CH}_{3}\right), 1.27-1.38\left(\mathrm{~m}, 8 \mathrm{H}, 4 \mathrm{CH}_{2}\right), 1.42\left(\mathrm{t},{ }^{3} J=\right.$ $\left.7.6 \mathrm{~Hz}, 2 \mathrm{H}, \mathrm{CH}_{2}\right), 3.13\left(\mathrm{~s}, 3 \mathrm{H}, \mathrm{CH}_{3}\right) ;{ }^{13} \mathrm{C} \mathrm{NMR}(100 \mathrm{MHz}) \delta 14.46,23.05,24.31,27.56,30.12$, $31.98,34.74,48.56,135.00,135.96,137.13$, 137.85, 138.79, 139.73, 141.44, 141.99, 142.21, 142.30, 142.59, 142.80, 142.90, 143.06, 143.16, 143.65, 143.75, 143.80, 144.48, 144.61, 145.22.

1a-Methyl-1a-(3'-thiopentylprop-2'-yl)-1(9)a-homo $\left(\mathbf{C}_{\mathbf{6 0}}-\boldsymbol{I}_{\boldsymbol{h}}\right)$ [5,6]fullerene (6). IR (KBr) v 527, 1384, 1437, $1462 \mathrm{sm}^{-1}$; UV $\left(\mathrm{CHCl}_{3}\right) \lambda_{\max } 262,333 \mathrm{~nm} ;{ }^{1} \mathrm{H}$ NMR $(400 \mathrm{MHz}) \delta 0.94(\mathrm{~m}, 3 \mathrm{H}$, $\left.\mathrm{CH}_{3}\right), 1.04\left(\mathrm{~s}, 3 \mathrm{H}, \mathrm{CH}_{3}\right), 1.30-1.37\left(\mathrm{~m}, 6 \mathrm{H}, 3 \mathrm{CH}_{2}\right), 1.59\left(\mathrm{~d},{ }^{3} \mathrm{~J}=6.8 \mathrm{~Hz}, 3 \mathrm{H}, \mathrm{CH}_{3}\right), 2.58-2.66(\mathrm{~m}$, $\left.2 \mathrm{H}, \mathrm{CH}_{2}\right), 2.78\left(\mathrm{dd},{ }^{3} \mathrm{~J}=9.2\right.$ and $\left.12.8 \mathrm{~Hz}, \mathrm{H}^{\mathrm{a}}, \mathrm{CH}_{2}\right), 3.16\left(\mathrm{dd},{ }^{3} \mathrm{~J}=4.8\right.$ and $\left.12.8 \mathrm{~Hz}, \mathrm{H}^{\mathrm{b}}, \mathrm{CH}_{2}\right)$, $5.21\left(\mathrm{ddd},{ }^{3} \mathrm{~J}=4.8,6.8\right.$ and $\left.9.2 \mathrm{~Hz}, \mathrm{H}, \mathrm{CH}\right) ;{ }^{13} \mathrm{C} \mathrm{NMR}(100 \mathrm{MHz}) \delta 13.96,14.32,15.94,22.71$, 
29.96, 31.47, 33.30, 36.51, 42.31, 52.88, 135.13, 135.45, 135.57, 135.98, 137.80, 137.83, 138.80, $138.87,138.97,139.85,140.18,140.29,140.93,141.31,141.36,141.81,141.94,142.04,142.15$, $142.27,142.33,142.70,142.75,142.92,142.97,143.03,143.15,143.18,143.20,143.61,143.72$, $143.77,143.79,143.98,144.15,144.17,144.48,144.86,144.88,145.20$; MS (MALDITOF/TOF) $m / z[M]^{+}$found 892.984 , calculated $892.972, \mathrm{C}_{70} \mathrm{H}_{20} \mathrm{~S}$.

1a-Methyl-1a-(3'-thiocyclohexylprop-2'-yl)-1(9)a-homo( $\left(\mathbf{C}_{60}-I_{h}\right)[5,6]$ fullerene (7). IR (KBr) $v$ $527,1385,1445,1462 \mathrm{sm}^{-1}$; UV $\left(\mathrm{CHCl}_{3}\right) \lambda_{\max } 262,332 \mathrm{~nm} ;{ }^{1} \mathrm{H}$ NMR $(400 \mathrm{MHz}) \delta 1.05(\mathrm{~s}, 3 \mathrm{H}$, $\left.\mathrm{CH}_{3}\right), 1.32\left(\mathrm{~m}, 2 \mathrm{H}, \mathrm{CH}_{2}\right), 1.36\left(\mathrm{q},{ }^{3} \mathrm{~J}=9.2 \mathrm{~Hz}, 2 \mathrm{H}, \mathrm{CH}_{2}\right), 1.59\left(\mathrm{~d},{ }^{3} \mathrm{~J}=6.8 \mathrm{~Hz}, 3 \mathrm{H}, \mathrm{CH}_{3}\right), 1.65-$ $1.68\left(\mathrm{~m}, 2 \mathrm{H}, \mathrm{CH}_{2}\right), 1.82\left(\mathrm{~m}, 2 \mathrm{H}, \mathrm{CH}_{2}\right), 2.04\left(\mathrm{q},{ }^{3} \mathrm{~J}=9.2 \mathrm{~Hz}, 2 \mathrm{H}, \mathrm{CH}_{2}\right), 2.71(\mathrm{~m}, \mathrm{H}, \mathrm{CH}), 2.76$ $\left(\mathrm{dd},{ }^{3} \mathrm{~J}=9.2\right.$ and $\left.13.2 \mathrm{~Hz}, \mathrm{H}^{\mathrm{a}}, \mathrm{CH}_{2}\right), 3.21\left(\mathrm{dd},{ }^{3} \mathrm{~J}=4.8\right.$ and $\left.13.2 \mathrm{~Hz}, \mathrm{H}^{\mathrm{b}}, \mathrm{CH}_{2}\right), 5.15-5.23(\mathrm{~m}, \mathrm{H}$, $\mathrm{CH}) ;{ }^{13} \mathrm{C}$ NMR $(100 \mathrm{MHz}) \delta 13.96,15.89,26.25,26.61,26.73,33.94,34.00,34.37,42.59$, $44.18,52.95,135.16,135.44,135.56,136.00,136.04,137.83,138.70,138.84,138.89,138.99$, $139.84,140.10,140.19,140.30,140.94,141.37,141.44,141.88,141.96,142.05,142.13,142.17$, $142.29,142.33,142.67,142.75,142.79,142.93,142.98,143.04,143.16,143.22,143.62,143.73$, $143.79,143.84,143.99,144.18,144.49,144.88,145.21,145.24,147.42,147.50$; MS (MALDITOF/TOF) $m / z[M]^{+}$found 905.032 , calculated $904.982, \mathrm{C}_{71} \mathrm{H}_{20} \mathrm{~S}$.

\section{Catalytic cycloaddition of diazoacetates to [60]fullerene. General procedure}

A solutions of $\mathrm{Pd}(\mathrm{acac})_{2}(0.00278 \mathrm{mmol})$ in $O$-dichlorobenzene $(0.4 \mathrm{~mL})$ and $\mathrm{PPh}_{3}(0.00556$ $\mathrm{mmol})$ in $o$-dichlorobenzene $(0.4 \mathrm{~mL})$ were mixted in the glas flask, then a solution of $\mathrm{Et}_{3} \mathrm{Al}$ $(0.01112 \mathrm{mmol})$ in toluene $(0.1 \mathrm{~mL})$ was added with stirring under stream of nitrogen at $-5{ }^{\circ} \mathrm{C}$. The color of the solution changed from light yellow to light brown. A solution of [60]fullerene $(0.0139 \mathrm{mmol})$ in $o$-dichlorobenzene $(0.1 \mathrm{~mL})$ was added to the resulting catalyst at room temperature, the color of the solution turned dark green. The mixture was heated to $80{ }^{\circ} \mathrm{C}$ and a solution of the corresponding diazo acetate $(0.0695 \mathrm{mmol})$ in $\mathrm{CH}_{2} \mathrm{Cl}_{2}(0.5 \mathrm{~mL})$ was added dropwise over a period of $5 \mathrm{~min}$. The reaction mixture was stirred for $1 \mathrm{~h}$ at the corresponding temperature, and then cooled to room temperature, treated with aqueous $\mathrm{HCl}$, extracted with toluene $(7 \mathrm{~mL})$. The organic layer was passed through short column filled with silica gel. The products 8-11 and [60]fullerene were separated by half-preparative HPLC, using toluene as eluent.

iso-Propyl 3'H-cyclopropa[1,9] $\left(\mathbf{C}_{60}-I_{h}\right)[\mathbf{5 , 6}$ fullerene-3'-carboxylate (8). IR ( $\mathrm{KBr}) v$ 540, 820, 1040, 1110, 1270, $1670 \mathrm{sm}^{-1}$; UV $\left(\mathrm{CHCl}_{3}\right) \lambda_{\max } 260,327,424 \mathrm{~nm} ;{ }^{1} \mathrm{H}$ NMR $(400 \mathrm{MHz}) \delta 1.54$ $\left(\mathrm{d},{ }^{3} \mathrm{~J}=6.0 \mathrm{~Hz}, 6 \mathrm{H}, 2 \mathrm{CH}_{3}\right), 4.74(\mathrm{~s}, \mathrm{H}, \mathrm{CH}), 5.38(\mathrm{~m}, 1 \mathrm{H}, \mathrm{CH}) ;{ }^{13} \mathrm{C} \mathrm{NMR}(100 \mathrm{MHz}) \delta 22.14$, 39.61, 70.36, 70.84, 136.64, 140.67, 140.99, 141.23, 142.00, 142.18, 142.32, 142.50, 142.87 , $143.04,143.11,143.13,143.40,143.78,144.02,144.47,144.68,144.72,144.92,145.13,145.23$, 145.28, 145.63, 145.83, 148.36, 165.43; MS (MALDI-TOF/TOF) $\mathrm{m} / \mathrm{z}[\mathrm{M}]^{+}$found 820.787, calculated $820.758, \mathrm{C}_{65} \mathrm{H}_{8} \mathrm{O}_{2}$.

Cyclohexyl 3'H-cyclopropa[1,9]( $\left(\mathbf{C}_{60}-I_{h}\right)[5,6]$ fullerene-3'-carboxylate (9). IR ( $\left.\mathrm{KBr}\right) v$ 570, 1040,1060, 1220, 1480, 1660, $1750 \mathrm{sm}^{-1}$; UV $\left(\mathrm{CHCl}_{3}\right) \lambda_{\max } 262,326,427 \mathrm{~nm} ;{ }^{1} \mathrm{H}$ NMR (400 $\mathrm{MHz}) \delta 1.20-2.20\left(\mathrm{~m}, 10 \mathrm{H}, 5 \mathrm{CH}_{2}\right), 4.75(\mathrm{~s}, \mathrm{H}, \mathrm{CH}), 5.05-5.16(\mathrm{~m}, 1 \mathrm{H}, \mathrm{CH}) .{ }^{13} \mathrm{C} \mathrm{NMR}(100$ 
$\mathrm{MHz}) \delta 24.27,25.93,32.15,39.79,70.91,75.25,136.64,140.69,140.99,141.25,142.02$, $142.19,142.31,142.50,142.88,143.03,143.13,143.40,143.79,144.03,144.47,144.69,144.72$, 144.93, 145.16, 145.23, 145.28, 145.63, 145.87, 148.36, 164.80; MS (MALDI-TOF/TOF) m/z $[\mathrm{M}]^{+}$found 860.770 , calculated $860.822, \mathrm{C}_{68} \mathrm{H}_{12} \mathrm{O}_{2}$.

tert-Butyl 3' $H$-cyclopropa[1,9] $\left(\mathbf{C}_{60}-I_{h}\right)[5,6]$ fullerene-3'-carboxylate (10). See ref. ${ }^{3 \mathrm{~d}}$ Cholesteryl 3'H-cyclopropa[1,9] $\left(\mathbf{C}_{60}-I_{h}\right)[\mathbf{5 , 6}]$ fullerene-3'-carboxylate (11). IR (KBr) $v 527$, 756, 1186, 1436, 1464, 1629, 1737, 2865, $2931 \mathrm{sm}^{-1}$; UV $\left(\mathrm{CHCl}_{3}\right) \lambda_{\max } 259,327,426 \mathrm{~nm} ;{ }^{1} \mathrm{H}$ NMR $(400 \mathrm{MHz}) \delta 0.74\left(\mathrm{~s}, 3 \mathrm{H}, \mathrm{CH}_{3}\right), 0.90\left(\mathrm{~d}, J=6.8 \mathrm{~Hz}, 3 \mathrm{H}, \mathrm{CH}_{3}\right), 0.91(\mathrm{~d}, J=6.8 \mathrm{~Hz}, 3 \mathrm{H}$, $\left.\mathrm{CH}_{3}\right), 0.99-2.05\left(\mathrm{~m}, 27 \mathrm{H}, 6 \mathrm{CH}, 9 \mathrm{CH}_{2}, \mathrm{CH}_{3}\right), 1.14\left(\mathrm{~s}, 3 \mathrm{H}, \mathrm{CH}_{3}\right), 2.06-2.11\left(\mathrm{~m}, 2 \mathrm{H}, \mathrm{CH}_{2}\right), 2.60(\mathrm{~d}$, $\left.J=8.0 \mathrm{~Hz}, 2 \mathrm{H}, \mathrm{CH}_{2}\right), 4.74(\mathrm{~s}, \mathrm{H}, \mathrm{CH}), 4.96(\mathrm{~m}, 1 \mathrm{H}, \mathrm{CH}), 5.49(\mathrm{~m}, 1 \mathrm{H}, \mathrm{CH}) ;{ }^{13} \mathrm{C} \mathrm{NMR}(100$ $\mathrm{MHz}) \delta 12.17,19.03,19.60,21.43,22.87,23.12,24.24,24.77,28.42,28.73,30.16,32.06,32.39$, $36.10,36.55,36.81,37.36,38.48,39.65,39.83,40.11,42.49,50.25,56.42,56.95,70.87\left(s^{3}\right)$, $76.40,123.66,139.09,140.70,140.95,141.24,142.07,142.50,142.81,143.03,143.37,143.78$, $144.02,144.65,144.68,145.13,145.22,145.29,145.83,148.58,164.79$; MS (MALDITOF/TOF) $\mathrm{m} / \mathrm{z}[\mathrm{M}]^{+}$found 1147.542 , calculated $1147.316, \mathrm{C}_{89} \mathrm{H}_{46} \mathrm{O}_{2}$.

\section{Acknowledgements}

The work was financially supported by FTP "Scientific and scientific-pedagogical personnel of innovative Russia” in 2009-2013 (Contract № P1218 and № 14.740.11.0014).

\section{References}

1. (a) Diederich, F.; Isaacs, L.; Philp, D. Chem. Soc. Rev. 1994, 23, 243. (b) Diederich, F.; Thilge, C. Science 1996, 271, 317. (c) Yurovskaya, M. A.; Trushkov, I. V. Russ. Chem. Bull. 2002, 51, 367. (d) Hirsch, A. Synthesis 1995, 895. (e) Thilgen, C.; Diederich, F. Chem. Rev. 2006, 106, 5049. (f) Reinov, M. V.; Yurovskaya, M. A. Russ. Chem. Rev. 2007, 76, 715. (g) Troshin, P. A.; Lyubovskaya, R. N. Russ. Chem. Rev. 2008, 77, 305.

2. (a) Troshin, P. A.; Lyubovskaya, R. N., Razumov, V. F. Nanotechnologies in Russia 2008, 3(5-6), 242. (b) Da Ros, T.; Prato, M. Chem. Commun. 1999, 663. (c)

3. (a) Prato, M.; Lucchini, V.; Maggini, M.; Stimpfl, E.; Scorrano, G.; Eiermann, M.; Suzuki, T.; Wudl, F. J. Am. Chem. Soc. 1993, 115, 8479. (b) Pellicciari, R.; Natalini, B.; Amori, L.; Marinozzi, M.; Seraglia, R. Synlett 2000, 1816. (c) Li, Z.; Bouhadir, K. H.; Shevlin, P. Tetrahedron Lett. 1996, 37, 4652. (d) Isaacs, L.; Wehrsig, A.; Diederich, F. Helv. Chim. Acta. 1993, 76, 1231. (e) Zhu, C. C.; Xu, Y.; Liu, Y. Q.; Zhu, D. B.; J. Org. Chem. 1997, 62, 1996. (f) Nakamura, Y.; Inamura, K.; Oomuro, R.; Laurenco, R.; Tidwell, T. T.; Nishimura, J.; Org. Biomol. Chem. 2005, 3, 3032. 
4. (a) Pellicciari, R.; Annibali, D.; Constantino, G.; Marinozzi, M.; Natalini, B.; Synlett 1997, 1196. (b) Sokolov, V. I.; Nefedova, M. N.; Potolokova, T. V.; Bashilov, V. V. Pure Appl. Chem. 2001, 73, 275. (c) Pellicciari, R.; Natalini, B.; Potolokova, T. V.; Marinozzi, M.; Nefedova, M. N.; Peregudov, A. S.; Sokolov, V. I. Synthetic Commun. 2003, 33, 903.

5. Tuktarov, A. R.; Korolev, V. V.; Dzhemilev, U. M. Russ. J. Org. Chem. 2010, 46, 588.

6. Tuktarov, A. R.; Akhmetov, A. R.; Sabirov, D. Sh.; Khalilov, L. M.; Ibragimov, A. G.; Dzhemilev, U. M. Russ. Chem. Bull. 2009, 58, 1724.

7. Tuktarov, A. R.; Akhmetov, A. R.; Kamalov, R. F.; Khalilov, L. M.; Pudas, M.; Ibragimov, A. G.; Dzhemilev, U. M. Russ. J. Org. Chem. 2009, 45, 1168.

8. Tuktarov, A. R.; Akhmetov, A. R.; Khalilov, L. M.; Dzhemilev, U. M. Russ. Chem. Bull. 2010, 59, 611. 